DOI: 10.24125/sanamed.v12i2.182

\title{
THE BURDEN OF VESICO-VAGINAL FISTULA IN ILE-IFE, SOUTH WESTERN NIGERIA
}

\author{
Fehintola O. Akintunde, ${ }^{1}$ Badejoko O. Olusegun, ${ }^{1}$ Ijarotimi O. Adebimpe, \\ Bakare Babatola, ${ }^{2}$ Fehintola O. Funmito, ${ }^{3}$ Adeyemi B. Adebanjo ${ }^{1}$ \\ ${ }^{1}$ Department of Obstetrics, Gynaecology, and Perinatology, \\ Obafemi Awolowo University, Ile-Ife, Osun- State, Nigeria \\ 2 Department of Obstetrics \&Gynaecology, State Hospital, Ondo, Ondo-State, Nigeria \\ ${ }^{3}$ Department Community Health, Obafemi Awolowo University, Ile-Ife, Osun- State, Nigeria
}

Primljen/Received 20. 04. 2017. god.

Prihvaćen/Accepted 01. 07. 2017. god.

Abstract: Background: Vesicovaginal fistula is a major cause of severe morbidity and potential mortality, which can result in marital disruption, rejection, and eventual destitution.

Methodology: A retrospective study of all cases of vesicovaginal fistula managed over a 30 year period between $1^{\text {st }}$ January 1984 and $31^{\text {st }}$ December 2013 at the Obafemi Awolowo University Teaching Hospitals Complex, Ile-Ife, Osun State, Nigeria.

Relevant data were obtained from the case notes and analyzed for the demographics, clinical features, management and outcome using SPSS version 20.

Result: There were 213 patients with vesicovaginal fistula over the period of the study with aprevalence of 3.9 per 1000 deliveries. The age range was 15-45 years with a mean age of 24.8 years. Most of them were primiparous, $(52.1 \%)$ and of the low social class (84.5\%). Obstetric fistula accounted for $93.9 \%$. The majority of them $(64.8 \%)$ did not have antenatal care during the antecedent pregnancy. Labor was attended by unskilled attendants in about $90 \%$ of them while $92 \%$ labored for at least 24 hours. The juxta-cervical fistula was the most common anatomical type (47.0\%). The overall success rate at repair was $76.4 \%$. Stillbirth rate in the antecedent pregnancy was $67.5 \%$. Other associated morbidities included chronic vulva excoriation, obstetric palsy, and secondary amenorrhea.

Conclusion: Vesicovaginal fistula (VVF) is a major public health problem in developing countries with too many calamities as shown in this study. Improving the educational and economic status of women in $\mathrm{Ni}$ geria will go a long way in empowering them to access quality antenatal care. This will also enhance hospital delivery thereby preventing prolonged obstructed la- bor which is a strong etiological factor for VVF. Decentralization of treatment centers and training of specialists in fistula surgery is very important to improving treatment outcomes.

Key words: Burden, Obstructed labor, Vesicovaginal fistula.

\section{INTRODUCTION}

Vesicovaginal fistula is an abnormal communication between the epithelium of the bladder and vagina. It is a very unpleasant experience for the patients and is considered as one of the most dehumanizing conditions that affect women who often experience a lot of social problems (1).

Vesicovaginal fistula is rare in the developed world but still remains a public health problem in developing countries. This condition is much more prevalent in Northern Nigeria than the southern Nigeria where it is estimated that more than 150000 unrepaired fistulae still exist (1).

Globally, a staggering estimate of at least 2 million women live with vesicovaginal fistula, the majority of them in the developing countries, typically represented by the VVF belt of sub-Saharan countries where Maternal Mortality Ratio (MMR) is very high. Indeed, the prevalence mirrors that of VVF in this zone (2). World Health Organization (WHO) estimated that for each maternal death, 10-15 other women sustain serious morbidity including obstetric fistula (3).

The incidence of vesicovaginal fistula tends to reflect the level of provision and usage of obstetric services in a community. These problems are particularly acute in Nigeria where at least $1 \%$ of all pregnant wo- 
men will die of obstetric complications and obstructed labor $(3,4)$. Women who survive obstructed labor often develop vesicovaginal fistula which remains a major cause of maternal morbidity. The incidence reported in Nigeria varies between 1.4 and 3.4 per thousand deliveries and incidence of urogenital fistula following hysterectomy in England and Wales is about 1 per 1300 operations (4).

Prolonged obstructed labor remains the commonest etiological factor of vesicovaginal fistula in the developing countries while iatrogenic damage during gynecological surgeries is the commonest factor in developed countries. Other causes include traditional practices like 'Gishiri cut'; radiation therapy for genital malignancy; advanced genital malignancies like carcinoma of the cervix, vagina; obstetric procedures like forceps and vacuum deliveries, destructive operations and infection such as Lymphogranuloma venerum (LGV), Schistosomiasis (1).

Vesicovaginal fistula characteristically presents as uncontrollable leakage of urine per vaginal and the patient may, therefore, smell of urine. Other associated features in obstetric fistula include vaginal scarring, loss of tissue from the bladder or urethra and vulva excoriations from ammoniacal dermatitis $(5,6)$.

Amenorrhea and secondary infertility may be present. The patient may show acquired deformity of the extremities from neurological injuries to the sciatic and common peroneal nerves6. The loss of their baby and the stench of urinary and/or fecal incontinence traumatize them psychologically resulting in loss of self-esteem, they become withdrawn from the society and may be abandoned by the relatives including husband $(1,2)$.

Surgical closure is the definitive treatment once the diagnosis is made but the timing depends on the cause of the injury. Early closure of fistula is indicated in cases occurring at surgery, while a period of delay of about 2-3 months is advocated for cases resulting from prolonged obstructed labor and may be up to a year for radiation-induced fistula (1).

However, early closure of fresh obstetric fistulae soon after the sloughs have disappeared has been reported with good success and currently being advocated by some authors (7). Catheter treatment of fistulae is also recognized as an initial management of urinary fistula with reported spontaneous closure of small fistulae. Extensive fistulae, however, may require grafts for closure to be successful.

The success of vesicovaginal fistula repair depends largely on post-operative nursing care. With good surgical techniques and sound post-operative care, prognosis is good.

Obafemi Awolowo University Teaching Hospital Complex is located in a semi-urban part of Southwest- ern Nigeria. The incidence of unsupervised labor is high in our environment and the attendant short and long-term complications are still seen in our practice. This retrospective study is therefore designed to determine the incidence, etiological factors, pattern of presentation and the outcome of repair of vesicovaginal fistula in our institution.

\section{MATERIALS AND METHODS}

This was a retrospective study of all cases of vesicovaginal fistulae managed at the Ife Hospital Unit of the ObafemiAwolowo University Teaching Hospital Complex, Ile-Ife, Nigeria from $1^{\text {st }}$ January 1984 to $31^{\text {st }}$ December 2013.

The case notes of the patients were retrieved from the Medical Records Department and data on parity, age, anatomical type and duration of fistula, size of fistula, aetiological factor, associated morbidities and outcome of surgical treatment were extracted. The analysis was done using SPSS version 20. The results were expressed in simple percentages. Information on the educational status of the patient and the job description of the husband were used for socio - economic stratification into class 1 to 5 according to Olusanya et al (8). In this study, classes 1 and 2 were grouped as upper social class, class 3 as middle social class while classes 4 and 5 were grouped as lower social class to aid data analysis. Only those cases of VVF with the proper record of one form of management or the other were included in the study. Cases with incomplete or missing record were excluded. Ethical clearance was obtained from the ethics and research committee of the Obafemi Awolowo University Teaching Hospitals Complex, Ile-Ife before the commencement of the study.

\section{RESULTS}

The age range was between 15 and 45 years with a mean age of 24.8 years. The peak prevalence was in the 15-24 year age group. The highest prevalence of VVF was in the primiparous patients constituting a total of 111 women (52\%). About 90 women (42.2\%) were Para $2-4$, while 12 women $(5.8 \%)$ were para5 and above. About 16 women (7.8\%) belonged to the upper social class while 180 women $(84.3 \%)$ belonged to the lower social class. The majority of the patients, 138 (64.8\%), who had VVF didn't receive antenatal care during the antecedent pregnancy while 75 $(35.3 \%)$ of them had antenatal care. Two hundred women $(93.9 \%)$ had obstetric related cause while 13 women $(5.9 \%)$ had non-obstetric related cause as shown in Table 1 above. 
Table 1. Sociodemographic characteristics and etiologies of vesicovaginal fistula(VVF) in patients seen at OAUTHC Ile-Ife

\begin{tabular}{|c|c|c|}
\hline Variable & $\begin{array}{c}\text { Frequency } \\
\mathrm{N}=213\end{array}$ & Percentage \\
\hline $\begin{array}{l}\text { Age group } \\
15-24 \\
25-34 \\
35-44\end{array}$ & $\begin{array}{c}111 \\
65 \\
37\end{array}$ & $\begin{array}{l}52.1 \\
30.5 \\
17.4\end{array}$ \\
\hline $\begin{array}{l}\text { Parity } \\
1 \\
2 \\
3 \\
4 \\
\geq 5\end{array}$ & $\begin{array}{c}111 \\
58 \\
25 \\
7 \\
12\end{array}$ & $\begin{array}{l}52.1 \\
27.2 \\
11.7 \\
3.3 \\
5.7\end{array}$ \\
\hline $\begin{array}{l}\text { Educational Status } \\
\text { No formal/Primary } \\
\text { Secondary } \\
\text { Tertiary }\end{array}$ & $\begin{array}{c}150 \\
45 \\
18\end{array}$ & $\begin{array}{c}70.4 \\
21.1 \\
8.5 \\
\end{array}$ \\
\hline $\begin{array}{l}\text { Social Class } \\
\text { Upper } \\
\text { Middle } \\
\text { Lower }\end{array}$ & $\begin{array}{c}16 \\
17 \\
180\end{array}$ & $\begin{array}{c}7.5 \\
8.0 \\
84.5\end{array}$ \\
\hline $\begin{array}{l}\text { Booking Status } \\
\text { Booked } \\
\text { Un-booked }\end{array}$ & $\begin{array}{c}75 \\
138 \\
\end{array}$ & $\begin{array}{l}35.2 \\
64.8 \\
\end{array}$ \\
\hline $\begin{array}{l}\text { Etiologies of VVF } \\
\text { Obstetric related causes } \\
\text { Iatrogenic causes } \\
\text { Malignancies }\end{array}$ & $\begin{array}{c}200 \\
9 \\
4\end{array}$ & $\begin{array}{c}93.9 \\
4.2 \\
1.9\end{array}$ \\
\hline
\end{tabular}

During the period of study, there were 56154 deliveries and 213 cases of vesicovaginal fistula giving a prevalence of 3.9 per 1000 deliveries. Figure 1 below showed increase in incidence of VVF during the period under review.

Approximately 184 women (92\%) out of those who developed fistula from obstetric related cause were in labor for at least 24 hours with labor duration ranging from 1-5 days and the mean duration was 2.3 days. About $180(90 \%)$ of the patients had unsupervi-

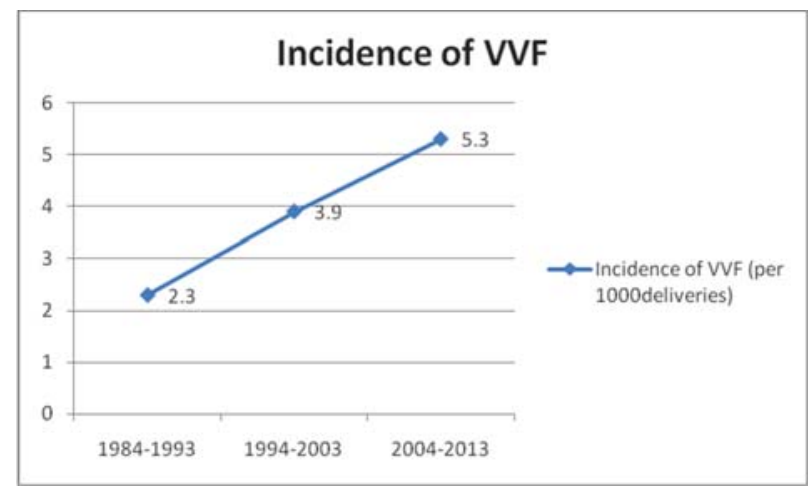

Figure 1. Trend of the incidence of VVF at OAUTHC Ile-Ife
Table 2. Place of delivery, duration of labour, mode of delivery, and fetal outcome at OAUTHC Ile-Ife

\begin{tabular}{|l|c|c|}
\hline \multicolumn{1}{|c|}{ Variables } & $\begin{array}{c}\text { Frequency } \\
\text { N=200 }\end{array}$ & Percentage \\
\hline Place of Labour/delivery & & \\
At home & 63 & 31.5 \\
Mission Home & 117 & 58.5 \\
Private hospital & 10 & 5.0 \\
Government hospital & 10 & 5.0 \\
\hline Duration of Labour & & \\
$<24$ hours & 16 & 8.0 \\
24-72 hours & 146 & 73.0 \\
$>72$ hours & 38 & 19.0 \\
\hline Mode of delivery & 91 & \\
Spontaneous vaginal delivery & 21 & 10.5 \\
Instrumental vaginal delivery & 27 & 13.5 \\
Destructive operation & 47 & 23.5 \\
Caesarean section & 14 & 7.0 \\
Caesarean hysterectomy & & \\
\hline Fetal outcome & 65 & 32.5 \\
Alive & 135 & 67.5 \\
Dead & & \\
\hline
\end{tabular}

Table 3. Anatomical type and size of fistula in patients with obstetric vesico-vaginal fistula at OAUTHC Ile-Ife

\begin{tabular}{|l|c|c|}
\hline \multicolumn{1}{|c|}{ Variable } & $\begin{array}{c}\text { Frequency } \\
\mathbf{N = 2 0 0}\end{array}$ & Percentage \\
\hline Anatomical type & & \\
Juxta- cervical & 94 & 47.0 \\
Juxta-urethral & 67 & 33.5 \\
Mid-vagina & 39 & 19.5 \\
\hline Size of fistula & & \\
$<2 \mathrm{~cm}$ & 120 & 60.0 \\
$2-3 \mathrm{~cm}$ & 54 & 27.0 \\
$4-5 \mathrm{~cm}$ & 18 & 9.0 \\
$\geq 6 \mathrm{~cm}$ & 8 & 4.0 \\
\hline
\end{tabular}

sed labor at home and the mission houses while only 20 $(10 \%)$ women labored in health care facility as shown above. Of the 200 patients with obstetric cause, 109 $(54.5 \%)$ of them had some forms of operative delivery as shown below while the remaining $(45.5 \%)$ had spontaneous vaginal delivery. Prolonged labor contributed to poor perinatal outcome in these patients with stillbirths recorded in $135(67.5 \%)$ of the antecedent deliveries and live births in $65(32.5 \%)$ of patients.

Majority of the fistula are juxta-cervical fistula which accounted for $47.1 \%$ of cases. About 15 (7.5\%) of women with VVF had a concurrent rectovaginal fistula. The size of the fistula ranged between $2 \mathrm{~cm}-6$ $\mathrm{cm}$. About $120(60 \%)$ of the women had fistula less than $2 \mathrm{~cm}$ while only $8(3.9 \%)$ of them suffered extensive fistula. 


\section{MANAGEMENT OUTCOME}

Out of the 200 women with obstetric VVF, 180 $(90.0 \%)$ had VVF repair while $8(4.0 \%)$ were lost to follow-up before surgery. Twelve patients $(6.0 \%)$ had spontaneous closure with complete resolution of symptoms during prolonged catheterization. Transvaginal route of repair accounted for majority of the repair in $157(87.2 \%)$ of patients, while the transabdominal route was used in $23(12.8 \%)$ of patients. About 128 (71.1\%) of the 180 women had successful VVF repair at first attempt while additional $10(5.3 \%)$ achieved continence at second attempt with overall success rate of $76.4 \%$.

\section{ADDITIONAL MORBIDITIES}

There were other associated morbidities found in these patients. About $37.3 \%$ of them had chronic excoriation of the perineal skin due to ammoniacal dermatitis; obstetric palsy (foot drop) was observed in 37 $(18.3 \%)$ while $11.8 \%$ of the women had secondary amenorrhoea.

\section{DISCUSSION}

One of the most devastating consequences of obstructed labor is the vesicovagina fistula $(1,2)$. Approximately $94 \%$ of fistula in this series was due to obstetric causes. This was similar to findings of ljaiya et al where $84.1 \%$ of fistulae reported in their series were due to obstetric causes (4).

In the developing world, the true incidence of vesicovagina fistula is unknown, as many patients with this condition suffer in silence and isolation. Some estimates place the prevalence as high as 2 million women worldwide (6).

The prevalence of VVF of 3.9 per 1,000 deliveries in this study was similar to the estimated prevalence range of $3-4$ per 1,000 deliveries reported for West Africa (7) and 3.5 per 1,000 deliveries reported by Harrison in Kaduna (2). It is, however, higher than 1.4 per 1,000 deliveries reported from Ilorin (4).

This relatively high incidence from a southern hospital may be due to the fact that our Hospital is a referral center for about four states.

During normal labor, the bladder is displaced upwards in the abdomen so the anterior vaginal wall, bladder base, and urethra are compressed between the fetal head and the posterior part of the pubic bone. If this occurs for a short period of time, there is no tissue damage. If, however, there is prolonged obstructed labor, the intervening soft tissue becomes ischemic. The area undergoes pressure necrosis and within 3-10 days post partum, the tissue sloughs off.
Typically, the length of pressure without relief is more important than the magnitude of pressure. About $92 \%$ of women in this study were in labor for at least 24 hrs, with some labor lasting as long as 6 days. This result is similar to the series in fistula hospital in Addis Ababa where the average length of labor was 3.9 days (9).

The typical fistula patient is young, primiparous, separated from her partner and had little or no education. This is similar to findings in this study in which the mean age of majority of the patient was 24.8 years, $79.3 \%$ of the women were of low parity (para 1 and 2) and $84.5 \%$ belonging to lower social class (class IV and V).

This result is also similar to earlier studies $(4,10)$. The high prevalence in the young primiparous women may be due to the occurrence of cephalopelvic disproportion because the pelvis is not fully developed to allow for normal vaginal delivery $(11,12)$.

Furthermore, many of these patients have unsupervised labor with a resultant high incidence of prolonged obstructed labor and subsequent fistula formation. Because of the low level of literacy in these women, they maintain subordinate position in the society and are excluded from decision-making, even decision about their own health.

These and other contributing factors cause late presentation for treatment. The average duration of fistula before presentation for care in this study was 6.2 yrs. This is similar to mean duration reported by Sunday-Adeoye (13).

The pattern of prevalence of vesicovaginal fistula over the 30 years under review showed gradual increase with more and more patients presenting to our center for treatment. This mirrors the increased incidence of obstructed labor with its attendance complications. The reason for this increase as seen in some other African countries like Ethiopia is that the contributing factors still persist and even getting worse (14).

Many women in developing countries have contracted pelvis, most often as a result of malnutrition and increased infection rate in adolescent leading to growth stunting and poor development. This is compounded by early marriage and childbearing and female genital mutilation $(12,13,14)$.

Many women rely on traditional healers and mission houses because they are viewed as more accessible and familiar. They view hospital as the place to die and not a place for delivery. Physical barriers that prevent hospital delivery include; limited transportation and poor road network (15).

Juxta-cervical fistula was the commonest type of fistulae in this study. This is similar to the findings in other studies $(13,16,17)$. This is probably due to the fact that obstruction in labor at the pelvic brim is commoner in this part of the world. 
The majority of the patients in this study presented with total urinary incontinence. About $14.7 \%$ of the patient presented with combined fistula (VVF and rectovaginal fistula).

Vaginal examination in the clinic was difficult in $98 \%$ of the patient because of vagina scaring with varying degree of dermatitis, gynaetresia and vulva excoriation necessitating Examination under anesthesia before accurate diagnosis could be made.

There are two routes to VVF repair - abdominal and vaginal routes. Some of the procedures that can be done through vaginal route include saucerization, flap sliding, Simple lay open etc. depending on the types of fistula. Contraindications to vaginal approach include: severely indurated vaginal epithelium around the fistula, small capacity or poorly compliant bladder, repair requiring ureteral reimplantation, involvement of other pelvic structures, vaginal stenosis, or inability to obtain proper exposure (18). The abdominal approach has been recommended for: high retracted fistulas in a narrow vagina; fistulas which are proximal to the ureters; cases with associated pelvic pathology, and multiple fistulas (18). Very high or large VVFs either in close proximity to ureteric orifices or when associated with hydronephrosis, hydroureter, or urinary ascites or absent vaginal cuff are considered to be complex fistulas and require a transabdominal transvesical approach. The successful management of such fistulas is largely dependent on judicious use of interposition flaps. The omental flap is undoubtedly the most versatile; it can be used in abdominal and combined abdominal-vaginal procedures. Surgery needs to be performed in a center of excellence and questions regarding adequacy of surgical experience, technical expertise, nursing care, and facilities for blood transfusion need to be addressed before attempting complex vesicovaginal repairs.

Moreover, the laparoscopic repair of vesicovaginal fistula without opening the bladder and using intracorporeal suturing and omentum interpositioning is a feasible procedure in selected patients. It will be a useful adjunct to transvaginal repair of fistulas if the surgical morbidity of the open abdominal approach is decreased. Laparoscopic VVF repair is most useful in the same scenarios as the transabdominal repair, such as in the setting of a high VVF in which a vaginal operation would be anatomically challenging. Although the laparoscopic approach in expert hands may provide high success rate, it is not widely practiced due to the costs and considerable learning curves imposed by intracorporeal laparoscopic suturing, a requirement for VVF repair, which is an advanced skill many surgeons lack $(19,20)$. Successful robotic VVF repair was first reported in 2005 (21). A five-port technique has been descri- bed using a vaginal pack to maintain pneumoperitoneum throughout the case (21).

In this study, approximately $85 \%$ of the VVF were not larger than $3 \mathrm{~cm}$ in diameter and were repaired transvaginally using either Saucerization or simple lay open technique. The combined fistulae repaired during the period under review were by the traditional three stage procedure. There were 12 cases of closure with flaps. There was no early closure in this study as advocated by some authors especially following hysterectomy (22).

Combined VVF and RVF used to be a three-stage procedure in which VVF repair is followed by diversionary colostomy and finally RVF repair (3 weeks later). Now combined VVF and RVF repair can be done at once with no need for diversion colostomy and $67 \%$ success rate in a study (23).

The overall success rate of $76.4 \%$ recorded in this series is in agreement with rates of $85 \%$ and $87.9 \%$ reported from other studies in Nigeria $(2,4)$. All the repairs were mainly through the vagina approach or occasionally abdominal.

Mode of delivery in subsequent pregnancy following successful repair could not be ascertained because there were no records of these in majority of the patients' case notes. However, 25 (18.2\%) of the patients with successful repair were delivered by Caesarean Section in their subsequent pregnancies.

The limitation of this study was the lack of follow-up and poor documentation of information. Data was scanty and poorly documented. Other limitations of this study were the fact that it was an institution-based study with the limited power on account of the small sample size. These limitations must be borne in mind when making extrapolations to the general population.

\section{CONCLUSION}

Vesicovaginal fistula (VVF) is a problem of under-development with too many calamities as shown in this study; as such the best solution will be by putting in place appropriate integrated development programs that are community-based and sustainable. Such approach should be one that will strengthen the local capacity available to women to improve their health and social environment through the implementation of coordinated model programs. Such programs should include those that address the social and economic status of the community as a whole with focus on girl-child education, adult literacy programs and income generating skills development for women of childbearing age. Also necessary are, appropriate, affordable and accessible health services provision at the grassroots 
level. This will enhance hospital delivery thereby preventing prolonged obstructed labor which is a strong etiological factor for VVF. Training of specialists in fistula surgery is very important to improving treatment outcomes.

\section{Competing interests} interests.

The authors declare that they have no competing

\section{Acknowledgements}

I am using this opportunity to acknowledge useful contributions from Professor Adesegun Fatusi, and Dr. Olorunfemi Ogundele of the community health department, Obafemi Awolowo University Teaching Hospi- tals Complex, Ile Ife, Osun State, Nigeria for their inputs in writing of this article.

\section{Disclosure statement:}

None of all authors

\section{Licensing}

This work is licensed under a Creative Commons Attribution 4.0 International (CC BY 4.0) Licence
Abbreviations
VVF - Vesicovaginal fistula
MMR - Maternal Mortality Ratio
WHO - World Health Organization
LGV - Lymphogranuloma venerum

\title{
Sažetak
}

\section{UČESTALOST VEZICO-VAGINALNIH FISTULA U ILE-IFE-u, U JUGO-ZAPADNOJ NIGERIJI}

\author{
Akintunde O Fehintola, ${ }^{1}$ Olusegun O Badejoko, ${ }^{1}$ Adebimpe O Ijarotimi, \\ Babatola Bakare, ${ }^{2}$ Funmito O Fehintola, ${ }^{3}$ Adebanjo B Adeyemi ${ }^{1}$ \\ ${ }^{1}$ Department of Obstetrics, Gynaecology, and Perinatology, Obafemi Awolowo University, Ile-Ife, Osun- State, Nigeria \\ ${ }^{2}$ Department of Obstetrics \&Gynaecology, State Hospital, Ondo, Ondo-State, Nigeria \\ ${ }^{3}$ Department Community Health, Obafemi Awolowo University, Ile-Ife, Osun- State, Nigeria
}

Uvod: Vezikovaginalna fistula je jedan od vodećih uzroka ozbiljnog morbiditeta i potencijalnog mortaliteta kod žena, koji se može reflektovati i na bračne probleme, socijalno marginalizovanje, odbijanje i eventualno u destituciji.

Metodologija: Retrospektivna studija svih slučajeva vezikovaginalnih fistula prikupljenih u proteklih 30 godina između 01. 01. 1984. i 31. 12. 2013. u Obafemi Awolowo Univerzitetskoj bolnici, Ile-Ife, država Osun, Nigerija. Relevatni podaci, prikupljeni iz istorija bolesti, analizirani su prema demografskim i kliničkim karakteristikama, pristupu u lečenju i ishodu, koristeći SPSS verziju 2.0.

Rezultati: 213 pacijenata sa vezikovaginalnom fistulom je obuhvaćeno studijom u navedenom period praćenja, sa prevalencom od 3,9 na 1000 pacijenata. Starost pacijenata se kretala između 15-45 godina sa srednjom vrednošću od 24,8 godina. Većina pacijentkinja su bile prvorotke $(52,1 \%)$ i pripadnice niže socijalne klase $(84,5 \%)$. Obstretična fistula se pojavila u $93,9 \%$. Većina $(64,8 \%)$ nije imala odgovarajuću ante- natalnu negu tokom trudnoće. Porođaj je vođen od strane nestručnog osoblja u oko $90 \%$ slučajeva, i kod $92 \%$ porođaj je trajao minimum $24 \mathrm{~h}$. Jukstacervikalna fistula je bila najčešći anatomski tip (47\%). Sveukupni uspeh korekcije je bio oko 76,4\%. Stopa mrtvorođenčadi je bila $67,5 \%$. Ostali morbiditeti su uključivali hronične ekskorijacije vulve, akušersku paralizu i sekundarnu amenoreju.

Zaključak: Vezikovaginalna fistula je veliki problem javnog zdravlja u zemljama u razvoju sa mnogo nesrećnih slučajeva, kao što je prikazano u ovoj studiji. Poboljšanje obrazovnog i ekonomskog položaja žena u Nigeriji će im omogućiti pristup kvalitetnijoj antenatalnoj nezi. Ovo će takođe povećati i broj porođaja vođenih u bolnici, što će biti prevencija produženog porođaja, koji je najznačajniji etiološki faktor u pojavi VVF. Decentralizacija ustanova, kao i edukacija specijalista u hirurgiji fistula je od esencijalnog značaja za unapređenje kvaliteta operacija i poboljšavanje ishoda.

Ključne reči: teret. produžen porođaj, vezikovaginalna fistula. 


\section{REFERENCES}

1. Hassan M A, Ekele B A. Vesicovaginal fistula: Do the patients know the cause?. Ann Afr Med. 2009; 8(2): 122-6.

2. Harrison KA. Vesicovaginal fistula and pregnancy. BJOG.2010: 117(1) 116.

3. Wall LL. Obstetric fistula is a "Neglected tropical disease". PLoSNegl Trop Dis. 2012: 6(8): e1769.

4. Ijaiya MA, Aboyeji AP, Ijaiya ZBB, Rahman AG, Olatinwo AW, Esuga SA et al. Vesicovaginal fistula: a review of nigerian experience. West Afr J Med. 2010; 29(5): 293-8.

5. Kirschner CV, Yost KJ, Du H, Karshima JA, Arrowsmith SD, Wall LL. Obstetric fistula: the ECWA Evangel VVF Center surgical experience from Jos, Nigeria. IntUrogynecol J. 2010; 21(12): 1525-33.

6. Hillary CJ, Osman NI, Hilton P, Chapple CR. The aetiology, treatment, and outcome of urogenital fistulae managed in Well- and Low-resourced countries: a systematic review. Eur Urol. 2016; 70(3): 478-92.

7. Arrowsmith SD, Ruminjo J, Landry EG. Current practices in treatment of female genital fistula: a cross sectional study. BMC Pregnancy Childbirth. 2010; 10(1):73.

8. Olusanya O, Okpere E, Ezimokhai M. The importance of social class in voluntary fertility control in a developing country. West Afri Med J. 1985; 4:205-11.

9. Wall LL. Overcoming phase 1 delays: the critical component of obstetric fistula prevention programs in resource-poor countries. BMC Pregnancy Childbirth. 2012; 12:68.

10. Alio AP, Merrell L, Roxburgh K, Clayton HB, Marty PJ, Bomboka L et al. Psycho-social impacts of vesico-vaginal fistula in Niger. Arch Gynecol Obstet. 2011: 284(2): 371-8.

11. Gharoro EP, Agholor KN. Aspects of psychosocial problems of patients with vesico-vaginal fistula. J Obstet Gynaecol. 2009; 29 (7): 644-7.

12. Tebeu PM, Fomulu JN, Khaddaj S, de Bernis L, Delvaux T, Rochat CH. Risk factors for obstetric fistula: a clinical review. Int Urogynecol J. 2012; 23(4): 387-94.

\section{Correspondence to / Autor za korespondenciju}

Dr. Fehintola Akintunde Olusegun.

Department of Obstetrics, Gynaecology, and Perinatology,

Obafemi Awolowo University, Ile-Ife, Osun- State, Nigeria

Email address; akintunds@yahoo.com

Tell. no; +2348037998247
13. Sunday-Adeoye I, Okonta P, Ulu OL. Prevalence, profile and obstetric experience of fistula patients in Abakaliki, Southeast Nigeria. Urogynaecologia. 2011; 25(1):6.

14. Muleta M, Rasmussen S, Kiserud T. Obstetric fistula in 14,928 Ethiopian women. Acta Obstet Gynecol Scand. 2010; 89 (7): 945-51.

15. Khisa AM, NyamongoIK. What factors contribute to obstetric fistulae formation in rural Kenya?African Journal Of Midwifery And Women's Health. 2011; 5 (2): 95-100.

16. Subedi SS, Uprety D, Regmi M, Budhathoki B. 0905 Vesicovaginal fistula at Tertiary Care Center in Eastern Nepal. International Journal of Gynecology and Obstetrics. 2009; 107: S351.

17. Hardee K, Gay J, Blanc AK. Maternal morbidity: neglected dimension of safe motherhood in the developing world. Glob public health. 2012; 7(6): 603-17.

18. Frajzyngier V, Ruminjo J, Asiimwe F, Barry TH, Bello A, Danladi D, et al. Factors influencing choice of surgical route of repair of genitourinary fistula, and the influence of route of repair on surgical outcomes: findings from a prospective cohort study. BJOG. 2012; 119(11): 1344-53.

19. Rizvi SJ, Gupta R, Patel S, Trivedi A, Trivedi P, Modi P. Modified laparoscopic abdominal vesico-vaginal fistula repair - "Mini-O'Conor" vesicotomy. J Laparoendosc Adv Surg Tech A. 2010; 20(1): 13-5.

20. Zambon JP, Batezini NS, Pinto ER, Skaff M, Girotti ME, Almeida FG. Do we need new surgical techniques to repair vesico-vaginal fistulas? Int Urogynecol J. 2010; 21(3): 337-42.

21. Hemal A, Wadwa P. Robotic repair of vesico-vaginal fistula. In: Robotics in genitourinary surgery. London: Springer; 2011. pp. 611-16.

22. Lee JH, Choi JS, Lee KW, Han JS, Choi PC, Hoh JK. Immediate laparoscopic nontransvesical repair without omental interposition for vesicovaginal fistula developing after total abdominal hysterectomy. JSLS. 2010; 14(2): 187-91.

23. Hawkins L, Spitzer RF, Christoffersen Deb A, Leah J, Mabeya $\mathrm{H}$. Characteristics and surgical success of patients presenting for repair of obstetric fistula in western Kenya. International Journal of Gynecology \& Obstetrics. 2013; 120(2): 178-82. 